УДК 811.161 .2

DOI https://doi.org/10.26661/2414-1135-2021-83-18

\title{
ФОНЕТИЧНА ТЕРМІНОЛОГІЯ У «КОРОТКІЙ ГРАМАТИЦІ УКРАЇНСЬКОЇ МОВИ» (1906 РІК) П. ЗАЛОЗНОГО
}

\author{
Козелко I. P. \\ кандидат філологічних наук, старший викладач, \\ старший викладач кафедри українознавства \\ Львівський національний медичний університет імені Данила Галищького \\ вул. Пекарська, 69, Львів, Україна \\ orcid.org/0000-0002-4533-7868 \\ imatushchak@ukr.net
}

Ключові слова: лінгвістичний
термін, рідномовна основа
термінів, початок ХХ
ст., навчальний посібник,
термінотворчий процес.
У статті проаналізовано досягнення П. Залозного як укладача фонетичної термінології у «Короткій граматиці української мови» (Полтава, 1906 рік). «Граматика» П. Залозного була авторитетною працею Наддніпрянщини на початку XX ст., що грунтувалася на наукових позиціях В. Науменка (1889 рік), А. Соболевського (1891 рік), В. Коцовського й І. Огоновського (1904 рік), а також писалася з орієнтацією на термінологічний корпус мови, що його виробляли у Галичині. Ця праця була покликана навчити всіх, хто прагнув знати українську мову, саме тому їі основою $є$ рідномовні зв'язки. На початку XX ст. розділами граматик були переважно фонетика, морфологія, синтаксис тощо. У «Короткій граматиці української мови» П. Залозного виявлено лінгвістичні терміни, які вчений запропонував для навчання мови у шкільній освіті. У статті зосереджуємо увагу на термінах фонетики у граматиці вченого. Доведено, що фонетичні терміни, що їх фіксує «Коротка граматика української мови», входять та доповнюють лінгвістичну терміносистему П. Залозного. Виявлено, що лише у граматиці вчений вводить низку таких фонетичних термінів: «глухі самозвуки», «піднебенні співзвуки», «опуст». Для фонетичних термінів, якими оперує П. Залозний у своїй роботі, характерне частиномовне вираження. Приналежність цих термінів до тієї чи тієї частини мови відтворює авторський підхід вченого до вироблення фонетичної термінології. У граматиці П. Залозного переважають фонетичні найменування, які відображають модель «прикметник+іменник», менш вживаними $€$ терміни за структурою «іменник та іменник+іменник». Наголошено на цінності термінотворчої діяльності П. Залозного у контексті його доби. Вироблена фонетична термінологія у граматиці вченого сприяла гарному засвоєнню вчення про фонетику української мови. У статті стверджується, що термінологічну справу продовжували реалізовувати Г. Шерстюк та В. Коцовський, І. Огоновський у їхніх граматиках. Підтвердженням цієї думки $є$ абсолютний збіг фонетичних термінів у навчальних книгах вчених. 


\title{
PHONETICAL TERMINOLOGY IN P. ZALOZNY'S "SHORT GRAMMAR OF THE UKRAINIAN LANGUAGE" (1906)
}

\author{
Kozelko I. R. \\ Candidate of Philological Sciences, Senior Lecturer, \\ Senior lecturer at the Department of Ukrainian Studies \\ Danylo Halytskyi Lviv National Medical University \\ Pekarska str., 69, Lviv, Ukraine \\ orcid.org/0000-0002-4533-7868 \\ imatushchak@ukr.net
}

Key words: linguistic term, native language basis of terms, beginning of the XX century, textbook, terminological process.

\begin{abstract}
The article analyzes the achievements of P. Zalozny as a compiler of phonetical terminology in the "Short Grammar of the Ukrainian Language" (Poltava, 1906). P. Zalozny's grammar was an authoritative work of the Dnieper region in the beginning of the XX century, based on the scientific positions of V. Naumenko (1889), A. Sobolevsky (1891), V. Kotsovsky and I. Ogonovsky (1904), and was also written with a focus on the terminological corpus of the language, which was produced in Galicia. This work was designed to teach everyone who wanted to know the Ukrainian language, that's why it is based on native language connections. In the beginning of the XX century sections of grammars were mainly phonetics, morphology, syntax, and so on. P. Zalozny's «Short Grammar of the Ukrainian Language» reveals the linguistic terms that the scientist proposed for teaching the language in school education. The article focuses on the terms of phonetics in the grammar of the scientist. It is proved that the phonetical terms recorded by the "Short Grammar of the Ukrainian Language" are included in and complement the linguistic terminology system of P. Zalozny. It is found that only in grammar the scientist introduces a number of phonetical terms: «глухі самозвуки», «піднебенні співзвуки», «опуст». The phonetical terms used by P. Zalozny in his work are characterized by a partial linguistic expression. The affiliation of these terms to one or another part of the language reproduces the author's approach of the scientist to the development of the phonetical terminology. It should be noted that P. Zalozny's grammar is dominated the phonetical names that reflect the model adjective + noun, there are model terms noun and noun + noun which are less commonly used. The values of P. Zalozny's term-making activity in the context of his time are emphasized. The developed phonetical terminology in the grammar of the scientist contributed to the good mastering of the doctrine of the phonetics of the Ukrainian language. We claim that the terminological work continued to be realized by H. Sherstyuk and V. Kotsovsky, I. Ogonovsky in their grammars. Confirmation of this opinion is the absolute coincidence of the phonetical terms in the textbooks of scientists.
\end{abstract}

Постановка проблеми. Лінгвістична термінологія розглядається вченими у студіях, монографіях та дисертаціях впродовж кількох століть. Наукові поняття цієї терміносистеми розроблялися не одним поколінням граматистів. Увагу до лінгвістичних найменувань переважно 3 фонетики, морфології, синтаксису спостерігаємо вже в українських граматиках першої половини XX ст. Зокрема, найавторитетнішими є «Граматика руської мови» (1893 рік, 1914 рік) С. Смаль-Стоцького, Ф. Гартнера, «Коротка граматика української мови» (1906 рік) П. Залозного, «Коротка укра- їнська граматика для школи» (1907 рік) Г. Шерстюка, «Методична граматика руської мови» (1912 рік) В. Кочовського, I. Огоновського, «Граматика украӥнського язика» (1913 рік, 1914 рік) I. Нечуя-Левицького, "Украӥнська граматика» (1917 рік) $\epsilon$. Тимченка, «Початкова граматика украӥнської мови» (1918 рік) О. Курило, «Практична граматика української мови» (1918 рік) В. Сімовича, «Граматика украйнської мови для самонавчання та в допомогу шкільній научіџ» (1921 рік) В. Сімовича. У науці представлені поодинокі дослідження лінгвістичної термінології, 
що $є$ у цих граматиках. Так, О. Кацімон виявила глибоке зацікавлення мовознавчою термінологією, що ії вміщують граматики С. Смаль-Стоцького, Ф. Гартнера. Вчена вважає: «Саме в цьому шкільному підручнику запропоновано нову українську мовознавчу термінологію, що частково збереглася й у сучасній науці» [1, с. 47]. У цьому аспекті актуальним видається дослідження О. Крисяк, яка стверджує, що «Граматика руської мови» С. Смаль-Стоцького, Ф. Гартнера відіграла помітну роль у «становленні шкільної граматичної термінології, що використовується й у сучасному мовознавстві» [2, с. 66]. Отже, лінгвістична термінологія, укладена західноукраїнськими вченими С. Смаль-Стоцьким, Ф. Гартнером, функціонує частково і зараз, що дозволяє стверджувати про тяглість термінологічної традиції. Шкільні граматисти, які працювали на початку XX ст., проклали шлях для вироблення лінгвістичної термінології i на теренах Великої України. Вже у 1906 році П. Залозний видав «Коротку граматику української мови», що користувалася популярністю між українцями. Наша увага прикута до проблем становлення лінгвістичної терміносистеми у граматиках на початку XX ст., зокрема, до термінів фонетики, які розробляв П. Залозний у «Короткій граматиці української мови» (1906 рік), чим і зумовлена актуальність даного дослідження.

Мета і завдання статті. Мета статті - виявити та проаналізувати терміни фонетики у «Короткій граматиці української мови» П. Залозного, вказати на їхню частиномовну приналежність у мові.

Мета статті передбачає розв'язання таких завдань:

1) вказати на передумови творення фонетичних термінів у «Короткій граматиці української мови» П. Залозного, а також на їхню рідномовну основу;

2) виявити, які фонетичні терміни вживає П. Залозний у його навчальній книзі;

3) визначити частиномовне вираження фонетичних термінів, що їх уживає у граматиці П. Залозний;

4) з'ясувати роль лінгвістичної терміносистеми П. Залозного в контексті розвитку знання 3 фонетики української мови на початку ХX ст.;

5) показати вплив праці П. Залозного на термінотворчий процес початку XX ст.

Предмет та об'єкт дослідження. Предметом розвідки є закономірності розвитку лінгвістичної терміносистеми П. Залозного. Об'єкт дослідження - фонетична термінологія, що функціонувала на початку XX ст. у «Короткій граматиці української мови» П. Залозного.

Виклад основного матеріалу дослідження. У науці низку розвідок присвячено дослідженню історичного термінознавства. Зазначимо, що важливою складовою частиною історичного термінознавства $€$ термінотворчий процес початку $\mathrm{XX}$ ст. Уже в цей час особливого значення вчені надавали терміну, його виробленню та структурі. Читаючи навчальні книги, які виходили друком на початку XX ст., не можемо обминути увагою слова вчених про те, що граматику та лінгвістичну термінологію науковці творили, опираючись на літературне слово наших письменників. Л. Туровська зауважує: «У першій третині XX ст. основна увага науковців концентрувалася на збиранні термінів 3 усних і літературних джерел, подальшому створенні на цьому грунті національної термінології» [3, c. 67].

Початок XX ст. також позначений осмисленням граматики як такої, що відображає живомовні зв'язки. Як зазначав В. Сімович, проклався «новий шлях розуміння цієї гарної (бо живої) науки» $[4$, с. 4]. Граматисти укладають навчальні книги, акцентуючи увагу на україномовній їх основі, а також 3 опертям на діалект, який вони представляють. Однією з перших у Полтаві вийшла у світ «Коротка граматика української мови» П. Залозного (1906 рік), яка перевидавалася в 1913, 1917 та 1918 роках як «Початкова граматика української мови». Граматист зауважував, що під час укладання цієї навчальної книги він послуговувався такими працями, як-от: 1) «Методична граматика руської мови» В. Коцовского і І. Огоновского, 1904 р.; 2) «Обзоръ фонетическихъ особенностей малорусской рбчи» В. Науменко, 1889 р.; 3) «Лекціи по исторіи русскаго язика» А.І. Соболевскаго, 1891 p. [5, с. 4]. Вчений був послідовником їхніх наукових ідей. Проте П. Залозний мав на меті відроджувати українську школу у підросійській Україні, великі сподівання покладав на свою граматику. Він вважав, що на часі було писати «Коротку граматику української мови» українською мовою та адресувати її для широкого кола читачів. У передмові йдеться, що П. Залозний призначив «свою граматику не так для учнів, як для тих людей, що вже знають кілько граматик, окрім своєї» [5, с. 3]. Вкрай важливим для вченого було питання рідномовного поняттєво-термінологічного корпусу граматики, яка б доступно подавала мовні факти, щоб з неї могли вчитися всі бажаючі. 3 огляду на це П. Залозний за основу творення термінів фонетики брав галицькі терміни, бо він був прихильником наукових поглядів західноукраїнських граматистів В. Коцовського та І. Огоновського. Вчений зазначав: «У галицькій Україні наукові справи, а між ними й граматика, давно вже викладаються українською мовою. Там вироблені граматичні терміни із рідних слів. Завчити або зрозуміти їх зовсім легко навіть школяреві, що знає російську граматику. Тим-то беремо галицькі терміни майже цілком» [5, с. 3]. 
П. Залозний впроваджує національну лінгвістичну термінологію у «Короткій граматиці української мови». У ній учений виокремлює такі чотири розділи: І. Речення і його частини. II. Слово і його частини. III. Звуки та букви. VI. Частини мови. Правопис. Фонетика як розділ граматики йменується «Звуки та букви». У невеличкій за обсягом частині граматики зібрано чимало фонетичних термінів, які позначають назви звуків, наголос та інші фонетичні поняття: протинка, букви, отвертий склад, вставка звуків, самозвуки, гортанні співзвуки, губні співзвуки, замкнений склад, звуки, зубні співзвуки, мнякшення співзвуків, мнякі самозвуки, прилади вимовляння, наголос, носові співзвуки, повнозвучність, подвійні звуки, тихі співзвуки, сичачі співзвуки, постійний наголос, тверді самозвуки, азбука, чергування самозвуків, зміна самозвуків $i$ на $\check{u}, y$ на в, зміна співзвуків, глухе $b$, коротке $y$, коротке $i$, співзвуки, язичні співзвуки, плавні співзвуки, звучні співзвуки, шиплячі співзвуки. Виявлено, що у «Короткій граматиці української мови» П. Залозний вводить фонетичні терміни, які фіксує лише ця граматика: глухі самозвуки, піднебенні співзвуки, опуст.

Лінгвістичний термін в історичному аспекті має приналежність до частиномовного вираження. У колі науковців побутує думка про те, що у терміносистемах переважає іменниковий характер термінів. Так, у колективній монографії «Науково-технічний прогрес і мова» за редакцією В. Русанівського автори стверджують про майже цілковиту належність термінів до лексико-граматичного класу іменників [6, с. 81]. Натомість В. Даниленко доводить, що характерними для лінгвістичної термінології «<..>€ повнозначні слова - іменники, прикметники, прислівники, дієслова» [7, с. 37].

Проаналізуємо терміни фонетики 3 «Короткої граматики української мови» П. Залозного щодо рівня частиномовної уживаності. Серед виявлених нами фонетичних термінів найпродуктивнішими $є$ терміни, що у своєму складі поєднують структури «прикметник+іменник» (22 фоне- тичних терміни): отвертий склад, гортанні співзвуки, губні співзвуки, замкнений склад, зубні співзвуки, мнякі самозвуки, носові співзвуки, подвійні звуки, тихі співзвуки, сичачі співзвуки, постійний наголос, тверді самозвуки, глухе $b$, коротке $y$, коротке $i$, язичні співзвуки, плавні співзвуки, звучні співзвуки, шиплячі співзвуки, твердий звук, глухі самозвуки, піднебенні співзвуки; «іменник» (9 фонетичних термінів): протинка, букви, самозвуки, звуки, наголос, повнозвучність, азбука, співзвуки, опуст; «іменник+іменник» (6 фонетичних термінів): вставка звуків, мнякшення співзвуків, прилади вимовляння, чергування самозвуків, зміна самозвуків, зміна співзвуків.

На нашу думку, «Коротка граматика української мови» П. Залозного була грунтовною тогочасною методичною працею, в якій автор оперував фонетичними термінами, що переважно виражені структурною моделлю «прикметник+іменник».

В. Ващенко вважав єдиним недоліком граматики П. Залозного відсутність вправ та завдань, які є необхідними для опанування мови [8]. Констатуємо, що з огляду на фонетичну термінологію у «Короткій граматиці української мови» вченого пізнання фонетики, ії̈ вивчення було цілком можливим, бо вчений подав для опису звуків та інших фонетичних понять ті найменування, що розкривають сутність змісту фонетики. Отже, вагомою $\epsilon$ роль термінотворчої діяльності П. Залозного у контексті вчення про фонетику української мови на початку XX ст.

У статті прагнемо встановити, які фонетичні терміни вживають у граматиках послідовники П. Залозного. Г. Шерстюк та В. Коцовський, I. Огоновський писали навчальні книги для шкільного навчання, а також для усіх зацікавлених. У таблиці 1 «Зіставлення фонетичних термінів у «Короткій граматиці української мови» П. Залозного, «Короткій украйнській граматиці для школи» Г. Шерстюка, «Методичній граматииі руської мови» В. Кочовського, I. Огоновського» подаємо ті фонетичні терміни, які мають відповідники, що збігаються чи різняться у навчальних книгах вчених.

Таблица 1

\begin{tabular}{|c|c|c|c|}
\hline № & $\begin{array}{l}\text { «Коротка граматика } \\
\text { української мови» } \\
\text { (1906 р.) П. Залозного }\end{array}$ & $\begin{array}{c}\text { «Коротка украӥнська граматика } \\
\text { для школи» } \\
(1907 \text { р.) Г. Шерстюка }\end{array}$ & $\begin{array}{l}\text { «Методична граматика руської мови» } \\
\text { (1912 р.) В. Коцовського, } \\
\text { І. Огоновського }\end{array}$ \\
\hline 1 & 2 & 3 & 4 \\
\hline 1 & звуки (с. 6) & звук (с. 10) & звуки (с. 5) \\
\hline 2 & наголос (с. 8) & наголос (с. 8) & наголос (с. 13) \\
\hline 3 & співзвуки (с. 8) & співзвуки (с. 10) & співзвуки (с. 6) \\
\hline 4 & самозвуки (с. 8) & самозвуки (с. 10) & самозвуки (с. 6) \\
\hline 5 & букви (с. 6) & буква (с. 10) & букви (с. 5) \\
\hline 6 & мнякі самозвуки (с. 8) & мнякі самозвуки (с. 10) & мягкі самозвуки (с. 7) \\
\hline 7 & тверді самозвуки (с. 8) & тверді самозвуки (с. 10) & тверді самозвуки (с. 7) \\
\hline
\end{tabular}


Закінчення таблиці 1

\begin{tabular}{|c|c|c|c|}
\hline 1 & 2 & 3 & 4 \\
\hline 8 & носові співзвуки (с. 12) & носові співзвуки (с. 12) & носові співзвуки (с. 10) \\
\hline 9 & сичачі співзвуки (с. 12) & сичачі співзвуки (с. 12) & сичачі співзвуки (с. 10) \\
\hline 10 & язичні співзвуки (с. 12), & язичні співзвуки (с. 12), плавні & співзвуки (с. 12) \\
& плавні співзвуки (с. 12) & співзвуки (с. 10) \\
\hline 11 & шиплячі співзвуки (с. 12) & шиплячі співзвуки (с. 12) & шипячі співзвуки (с. 10) \\
\hline 12 & зубні співзвуки (с. 12) & зубні співзвуки (с. 11) & зубні співзвуки (с. 10) \\
\hline 13 & азбука (с. 7) & азбука (с. 10) & гортанні співзвуки (с. 10) \\
\hline 14 & гортанні співзвуки (с. 12) & гортанні співзвуки (с. 12) & губні співзвуки (с. 10) \\
\hline 15 & губні співзвуки (с. 12) & губні співзвуки (с. 11) & твердий співзвук (с. 8) \\
\hline 16 & твердий звук (с. 7) & наголосний значок (с. 9) &
\end{tabular}

3 поданої таблиці очевидним є факт про те, що термінотворча робота П. Залозного мала вплив на відбір термінів фонетики у «Короткій українській граматиці для школи» (1907 рік) Г. Шерстюка та «Методичній граматиці руської мови» (1912 рік) В. Коцовського, I. Огоновського. Зафіксовано такі терміноодиниці, які мають відмінне найменування у фонетиці в аналізованих граматиках, зокрема: мнякі самозвуки, шиплячі співзвуки (П. Залозний, Г. Шерстюк) - мягкі самозвуки, шипячі співзвуки (В. Коцовський, I. Огоновський); твердий звук (П. Залозний, В. Коцовський, І. Огоновський) наголосний значок (Г. Шерстюк).

Висновки і перспективи подальших розробок. Вважаємо, що П. Залозний був впливовим лінгводидактом Наддніпрянщини на початку XX ст. Його мовознавча діяльність, зокрема й термінологічна, заслуговує на те, щоб внести ім'я вченого в реєстр українських термінологів-лінгводидактів, що працювали на теренах Великої України на початку XX ст. Укладання «Короткої граматики української мови» П. Залозного викликане тогочасною потребою навчити українській граматиці не лише школяра, а й усіх, хто виявляє інтерес до мови та знає кілька граматик, окрім своєї. Ця граматика опиралась на термінологічний досвід також і галицьких граматистів. Як відмітив П. Залозний, галицькі лінгвістичні терміни варті уваги, тому чимало їх ужито в «Короткій граматиці української мови». Зазначимо, що фонетичні терміни у роботі вченого підібрані з орієнтацією на засоби рідної мови. За умов достатньої кількості фонетичних найменувань у «Короткій граматиці української мови» П. Залозного на початку XX ст. простежується частиномовна приналежність цих термінів до структур «прикметник+іменник», «іменник» та «іменник+іменник». Доводимо, що на початку $\mathrm{XX}$ ст. П. Залозний активізацією своєї термінологічної роботи сприяв відбору фонетичних термінів граматистами Г. Шерстюком, В. Коцовським, I. Огоновським. Для вчених цінною була думка П. Залозного, про що свідчать результати уживання однойменних фонетичних термінів. Перспективою подальших досліджень є опрацювання морфологічної термінології у «Короткій граматиці української мови» П. Залозного.

\section{ЛІТЕРАТУРА}

1. Кацімон О. Мовознавча термінологія у граматиках С. Смаль-Стоцького, Ф. Гартнера. Науковий вісник Чернівецького університету. 2010. Випуск 496-497. Слов'янська філологія. C. 47-60.

2. Крисяк О. І. «Руска граматика» С. СмальСтоцького та Ф. Гартнера як пам'ятка українського мовознавства. Освіта $i$ наука : Міжснародний науковий журнал. 2020. Вип. 1 (28). С. 65-69.

3. Туровська Л. Історичне термінознавство в Україні кінця XX - початку XXI ст. Украӥнська мова. 2012. № 2. С. 67-79.

4. Сімович В. Граматика української мови для самонавчання та в допомогу шкільній науці. Київ ; Ляйпціг : Укр. накладня. 1921. 584 с.

5. Залозний П. Коротка граматика української мови. Полтава : Електрична друкарня Г.І. Маркевича. 1906. Ч. 1. 64 с.

6. Науково-технічний прогрес і мова / відп. ред. В.М. Русанівський. К. : Наук. думка. 1978. 196 с.

7. Даниленко В.П. Русская терминология: опыт лингвистического описания. 1977. 245 с.

8. Ващенко В.С. Перші підручники з української мови. Украӥнська мова в школі. 1961. № 5. C. $81-87$.

\section{REFERENCES}

1. Katsimon, O. (2010) Linguistic terminology in the grammars of S. Smal-Stotsky, F. Gartner [Movoznavcha terminolohiia u hramatykakh S. Smal-Stotskoho, F. Gartnera]. Naukovyi visnyk Chernivetskoho universytetu, vol. 496-497, Slavic philology, pp. 47-60.

2. Krysiak, O.I. (2020) "Russian Grammar" by S. Smal-Stotsky and F. Gartner as a monument of Ukrainian linguistics ["Ruska hramatyka" S. Smal-Stotskoho ta F. Gartnera yak pamiatka 
ukrainskoho movoznavstva]. Mizhnarodnyi naukovyi zhurnal "Osvita i nauka", vol. 1 (28), pp. 65-69.

3. Turovska, L. (2012) Historical terminology in Ukraine in the end of the twentieth - beginning of the XXI century. [Istorychne terminoznavstvo $\mathrm{v}$ Ukraini kintsia XX - pochatku XXI st. Ukrainska mova, № 2, pp. 67-79.

4. Simovych, V. (1921) Grammar of the Ukrainian language for self-study and to help school science [Hramatyka ukrainskoi movy dlia samonavchannia ta $\mathrm{v}$ dopomohu shkilnii nautsi]. Kyiv ; Liaiptsig : Ukr. Nakladnia, 584 p.

5. Zaloznyi, P. (1906) Short grammar of the Ukrainian language [Korotka hramatyka ukrainskoi movy]. Poltava : Elektrychna drukarnia H. I. Markevycha, vol. 1, 64 p.

6. Naukovo-tekhnichnyi prohres i mova (1978) Scientific and technological progress and language / [vidp. red. V. M. Rusanivskyi]. K. : Nauk. Dumka, 196 p.

7. Danylenko, V.P. (1977) Russian terminology: The experience of linguistic description [Russkaia termynolohyia: Opyt lynhvystycheskoho opysanyia], $245 \mathrm{p}$.

8. Vashchenko, V.S. (1961) The first textbooks of the Ukrainian language [Pershi pidruchnyky $\mathrm{z}$ ukrainskoi movy]. Ukrainska mova v shkoli, № 5, pp. 81-87. 